\title{
Illness and cures in the Greek propitiatory inscriptions and dedications of Lydia and Phrygia
}

\section{ANGELOS CHANIOTIS}

\begin{abstract}
Summary The propitiatory inscriptions of Lydia and Phrygia (of the second and third centuries AD) manifest the belief that illness is a divine punishment for a sin (usually for a religious offence); cure can thus be achieved through expiation. Although scientific medicine was not unknown, the high costs of doctors, the belief in the omnipotence of gods, and the attribution of illness to divine intervention led the villagers to the local sanctuaries, where they received instructions by means of dreams and oracles. Some priests had medical experience, but they usually practised a 'religious healing' (incantations, purifications, sacrifices, the ritual transfer of the sin and the illness to animals).
\end{abstract}

This paper does not concern itself with a strictly medical aspect of ancient medicine, but with a subject which more properly belongs to the history of popular mentality; my objective is to show how simple, uneducated people reflected on their experiences of sickness and cure, especially of miraculous cure.

Beginning with Thucydides' description of the plague at Athens, Greek literature and Greek epigraphy offer several accounts of illness written by persons who either were suffering or had been cured; generally, such texts were written after a miraculous cure (e.g. the Sacred Tales of Aelius Aristides or inscriptions dedicated by individuals in sanctuaries of Asclepius in Athens, Epidaurus, Lebena, and Pergamon). ${ }^{1}$ These testimonies are undoubtedly of

I would like to express my thanks to Dr W. Furley (Heidelberg) and Dr V. Parker (Heidelberg) for critical remarks.

1 A collection of testimonies in Edelstein-Edelstein (1945) vol. 1, nos. 428 (Athens, second century AD), 432 (Epidaurus, second century AD), 439-441 (Lebena on Crete, first century BC); now add Müller (1987) 194 (Pergamon, second century AD). By contrast with these individual reports, the collections of healing miracles in Epidaurus, Lebena, and Rome were composed by the local priests and cannot be regarded as direct and personal reflections on sickness and cure. Epidaurus: IG IV ${ }^{2} .1$ 121-122 (late fourth century BC) = Edelstein-Edelstein (1945) vol. 1, nos. 423, 424; cf. Herzog (1931); Chaniotis (1988) 19-23 T 2 (with bibliography). Lebena (second century BC): I. Cret. I xvii. 8-12 = Edelstein-Edelstein (1945) vol. 1, no. 426; of. Chaniotis (1988) 51-52 T 2 (with bibliography). Rome (second/third century AD): IGUR 148 = Edelstein-Edelstein (1945) vol. 1, no. 438; cf. Chaniotis (1988) 86 T 21 (with bibliography). 
immense importance for the history of medicine and the history of religion alike. Usually the people who wrote them were educated individuals with deep religious feelings, but they were not unaware of the 'scientific' medicine of their times, to judge from their references to prescriptions and methods of healing.

In this paper I want to draw attention to a quite distinct group of such accounts known as the propitiatory inscriptions (or confession inscriptions). This term characterizes a group of inscriptions, mainly from the second and third centuries AD, found in Phrygia and Lydia. ${ }^{2}$ These texts, dedicated to various local deities and written in inelegant Greek, have a typical structure: a person confesses a sin committed by himself (or, in some cases, a relative); a deity has forced the sinner to his confession by punishing either him or a relative (usually with sickness, accident, or death). The illness is either specified in detail (Table 1 , thirty cases) or merely referred to in a general manner; ${ }^{3}$ sometimes the afflicted organ is represented in a recessed panel above the text. ${ }^{4}$ The sinner (or his relative) expiates the sin, warns other people not to underestimate the divine power, and praises the god. Of course, not all propitiatory inscriptions are as detailed as the pattern which I have just sketched; sometimes a general expression suffices to indicate the complex phenomenon of $\sin$, punishment, and repentance. ${ }^{5}$

The importance of these unaffected, simple texts written by people living in small villages in remote areas which never attracted the interest of our literary sources, is obvious. It is true that at least in some cases we have to assume that priests assisted the sinners in writing their confessions. ${ }^{6}$ But we are still

2 On the 'propitiatory inscriptions' in general see Steinleitner (1913); Zingerle (1926); Reitzenstein (1927) 137-141; Pettazzoni (1936) 54-115; Pettazzoni (1954) 57-59; Robert (1964) 23-33; Varinlioğlu (1983); Frisch (1983); Herrmann (1985); Petzl (1988). G. Petzl is preparing a new corpus of these texts. Kudlien (1978) offers a stimulating study of confession and cure in ancient Greece; some examples of diseases in the propitiatory inscriptions have been collected by Robert (1964) 25-27 and Petzl (1988) 156 note 11.

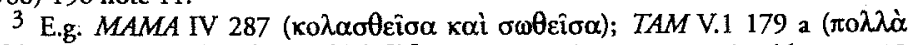

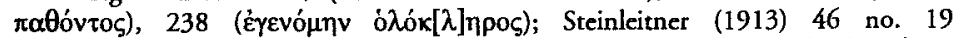

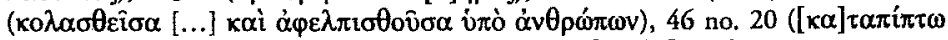

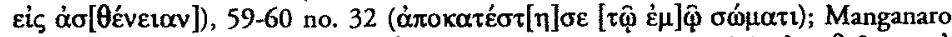

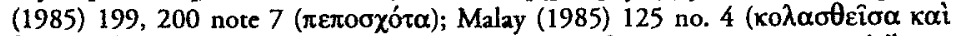

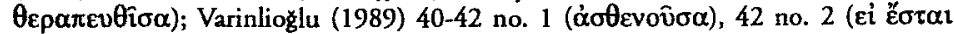

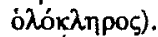

4 Van Straten (1981) 135-140.

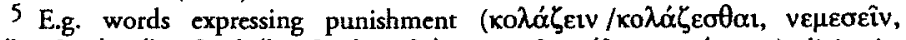

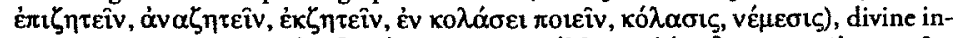

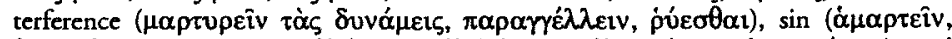

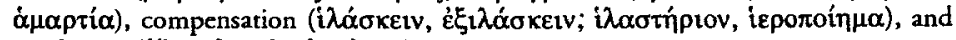

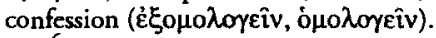

6 Cf. Varinlioglu (1989) 37. The use of standard expressions is a strong indication for the intervention of priests. 
dealing with individual accounts, which express in a direct way the feelings and attitudes of simple people towards illness, cure, medicine and doctors. Although the propitiatory inscriptions have often been discussed in relation to the history of ancient religion, their contribution to the history of medicine remains neglected (see note 2).

In this paper I also consider some dedications from the same geographical areas (Lydia and Phrygia) which refer to diseases and cure as well (Table 2). ${ }^{7}$ They are usually labelled as 'vows' (Ev̉xú). Vows and propitiatory inscriptions are closely relared, not only because at least some of the vows were made after the alleged punishment by the deity, ${ }^{8}$ but above all because both groups of texts were dedicated to the same gods and expressed the same religious feelings.

The importance of propitiatory inscriptions for ancient medicine lies in the first place in the close, causal relation between sin and illness, which is explicitly referred to in numerous texts. We have for example the confession of Diogenes:

'To Zeus Peizenos. Diogenes had made a vow for the ox, but he did not fulfil it; for that reason his daughter Tatiane was punished in her eyes. But now they propitiated and made the dedication'; 9

or the case of Stratonike:

'Stratonike the daughter of Mousaios took a loan from Eutychis, one modinos of the holy corn belonging to Axiottenos; however, she delayed repaying it until today. After she had been punished by the god in her right breast, she repaid the collected (sum) with all the interest and she praises Axiottenos.' 10

This causal relationship between sin and illness is not surprising; it manifests itseff already in the oldest Greek literary texts, the Homeric poems (e.g. in the

7 The representations of human organs in propitiatory inscriptions and dedications have been collected by van Straten (1981) 135-140 (35 cases). His no. 43.6 (right hand, palm forewards) is the representation of a gesture of adoration and not of a sick hand. The representation of male genitals and a pair of legs in MAMA IV 283 (= van

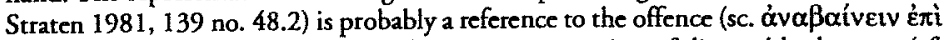

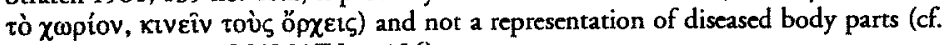
the commentary in $M A M A$ IV, p. 106).

8 E.g. MAMA IV 286; TAM V.1 541; Pleket (1978-1979) 90 no. 14; CremerNollé (1988) 203-205 no. 2.

9 TAMV.1 509.

10 Varinlioğlu (1989) 44-45 no. 3. 
first book of the Iliad), and remains vivid throughout Greek history, especially in popular religion and popular mentality.11 The earliest collection of Asclepius' 'healing miracles', the one composed in Epidaurus in the fourth century BC, includes some cases of persons who fell ill because of their sins, e.g. Kephisias:

'He laughed at the cures of Asclepius and said: "If the god claims he has healed lame people, he is lying. For, if he had the power to do so, why has he not cured Hephaistos?" But the god did not conceal that he was inflicting penalty for the insolence. For Kephisias, when riding, was struck by his bullheaded horse which had been tickled beneath the saddle, so that instantly his foot was crippled and he was carried into the temple on a stretcher. Later on, after he had entreated him earnestly, the god made him well.'12

We find here the same pattern as in the propitiatory inscriptions: sin, sickness, repentance, and cure. ${ }^{13}$

The propitiatory inscriptions provide much evidence for the persistence of this attitude in the villages of Lydia and Phrygia in the first centuries of our era. I begin my presentation of these texts with a study of the 'pathology' attested in them, i.e. the origin and the nature of illness. We will first consider the supposed causes of the diseases, in other words the sins which provoked the anger of gods and thus the affliction. ${ }^{14}$ In the texts that refer directly or indirectly to disease or death as punishment for a sin I distinguish the following categories of offences: ritual impurity - e.g. by eating forbidden food, wearing unclean clothes, having sexual intercourse etc. ${ }^{15}$ - damage to sanctu-

11 See e.g. Steinleitner (1913) 97-99; Rohde (1925) vol. 2, 76 note 1; Pettazzoni (1936) 62-63, 67-68; Kudlien (1978); Noorda (1979); Frisch (1983) 42-43; Burkert (1984) 59-61; Petzl (1988) 156; cf. Siebenthal (1950). For modern Greece see Danforth (1989) 74, 76-83, 92-93, 108-109.

$12 I G \mathrm{IV}^{2} .1123$ XXXVI; Herzog (1931) W 36; Edelstein-Edelstein (1945) vol. 1 no. 423,36 (with translation).

13 Cf. Kudlien (1978) 5-6 on two other cases of confession in the Epidaurian collection of healing miracles.

14 These offences do not differ essentially from those which had been punished in other ways than with illness or death. A representative collection of the offences attested in these text is found in Steinleitner (1913) 85-96 and Pettazzoni (1936) 59-61, 68-69.

15 TAM V.1 238, 261, 326, 467 (?), 541 (?); Steinleitner (1913) 59-60 no. 32; probably Herrmann-Polatkan (1969) 58-63 no. 15; Pleket (1978-1979) 90 no. 14; Herrmann-Varinlioğlu (1984) 2-3 no. 1; Herrmann (1985) 251-254 no. 1; Malay (1988) 151 no. 5; Varinlioğlu (1989) 45-47 no. 4; cf. also MAMA IV 280, 283, 284, $285,288,289$. 
aries and their possessions, ${ }^{16}$ the failure to fulfil a vow, ${ }^{17}$ refusal to offer services to a god or to attend the mysteries, ${ }^{18}$ perjury, ${ }^{19}$ unjustified curses, ${ }^{20}$ and theft or fraud. ${ }^{21}$ It is quite clear that we are dealing almost exclusively with religious offences, i.e. with ritual impurity and sacrilege, which can also be associated with impurity. ${ }^{22}$ The only exceptions are the few cases of theft; but in two of them theft is only one of the offences punished by the god (the others being of a religious nature).

The next question, what kind of diseases afflicted the sinners, is of course more important in our context. In half of the propitiatory inscriptions which permit an insight into the nature of the illness the afflicted organs were the eyes (Table 1, fourteen cases out of thirty). ${ }^{23}$ This accumulation of ocular disorders in our material is so large that it cannot be accidental. We might suppose that problems which had no obvious external causes or symptoms such as the loss of sight or mental diseases - (in contrast e.g. to wounds, ulcers, fever etc.) could more easily be attributed to divine intervention and divine punishment. Indeed, it seems to have been a widespread belief that blindness was a form of divine punishment. ${ }^{24}$ But this explanation is not satisfactory. The loss of sight was not just a problem for sinners, but also the most common illness (twelve out of seventy miracles) mentioned in the miraculous healings of Asclepius in Epidaurus. ${ }^{25}$ R. Herzog has pointed out that blindness is also the usual sickness mentioned in miraculous cures in general, and this holds true for Christian narratives as well. ${ }^{26}$ We may also add that among the 'anatomical votives', i.e. models and representations of the afflicted organ, 27 the eyes take a prominent position, especially in the Asclepieion at Athens and in

16 MAMA IV 279 (?), 287; TAM V.1 $179 \mathrm{a}$ and b, 264, 459; Herrmann (1985) 255-259 no. 2; Manganaro (1985) 200-201; Malay (1988) 149 no. 2, 150 no. 4; Varinlioglu (1989) 43-45 no. 3, 47 no. 5; perhaps Malay-Petzl (1985) 60-63 no. 4.

17. MAMA IV 286; TAMV.1 462, 509; Petzl-Malay (1987) 459-460; Malay (1988) 150 no. 3; Varinlioglu (1989) 42-43 no. 2.

18 MAMA IV 281; TAM V.1 460.

19 MAMA IV 279; TAM V.1 440, 464; Varinlioğlu (1983) 78-80 no. 2; MalayPetzl (1985) 63-64 no. 5 .

20 TAM V.1 318.

21 MAMA IV 279; TAM V.1 231, 251; Petzl-Malay (1987) 459-460.

22 Parker (1983) 144-146. In the case of Asclepius' miracles in Epidaurus (cited here according to the edition of Herzog) the sins are analogous: unwillingness to offer the thanksgiving dedication (W $7,22,47,55,60$ ?, 67), i.e. an attempt to cheat the god, mistrust of his healing powers (W $3,4,9,10,36$ ), and an attempt to spy on the $\operatorname{god}(W 11)$.

23 Cf. Pezl (1988) 156 note 11.

24 See for instance Esser (1961) 155-172; Petzl (1988) 156-157.

25 Herzog (1931) 95-97.

26 Herzog (1931) 95.

27 On the anatomical vorives see van Straten (1981) 105-151. 
the healing sanctuary of Ponte di Nona in Italy. ${ }^{28}$ If we consider the geographical area which concerns us here, Phrygia and Lydia, we observe that out of the forty-five dedications mentioning diseases cured (or expected to be cured) by a god, there are twelve cases of ocular disorders (Table 2). Blindness seriously affected the life of a person in antiquity and presented a grave social problem. In contrast with other diseases which could be treated by physicians, or at least led to a quick death and thus relieved the patient from his sufferings and the relatives from a burdensome care, in the case of blindness only a god could help. If the god refused to do so, one had to conclude that this was a punishment for a sin; and if the patient was actually cured - in whatever way -, it could not be explained by scientific medicine and had to be attributed to divine intervention.

Three sinners were punished with mental diseases:

'Trophime, the daughter of Artemidoros, the so called Kikinnas, had been called by the god to a service, but she did not want to go swiftly; for that reason the god punished her and made her insane. 29

The second inscription is very fragmentary, but we can recognize the verb

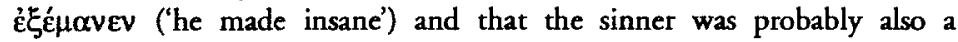

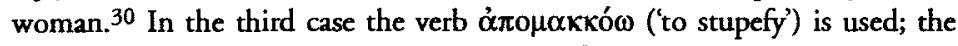
sinner was punished with speech impediment for three months and recovered his speech only after he had written down his sufferings on a stele. ${ }^{31}$ These mental disorders were probably attributed to divine punishment for reasons analogous to those stated above in relation to blindness. ${ }^{32}$ I should add here that in another propitiatory inscription the insanity of a man ( $\mu$ ovikì

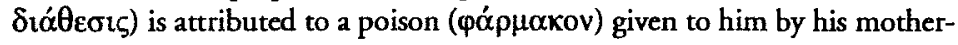
in-law. ${ }^{33}$

Another group of afflictions can be labelled as 'gynaecological problems'. In two cases the suffering organs were the buttocks of women:

28 Van Straten (1981) 108-113 nos. 1.25-31 (Asclepieion, 157 votives out of 401), 105-143 passim, 149-150; cf. Jackson (1988) 160-161.

29 TAM V.1 460. The word Oupodvoía found in Varinlioglu (1989) 47-49 no. 5 and interpreted by Varinlioglu (1989) 48 as a synonym for év0ovorooúó̧ has in fact

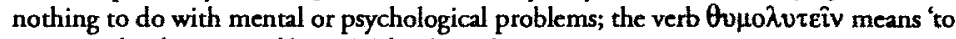
mitigate the divine wrath'; see Malay (1992).

30 TAM V.1 541.

31 Herrmann-Polatkan (1969) 58-63 no. 15.

32 Insanity is a common form of punishment mentioned in ancient imprecations; see for instance Zingerle (1926) 19; Robert (1964) 25 note 3. For modern Greece of. Danforth (1989) 76-81.

33 TAMV.1 318. 
'Glykia, daughter of Agrios, has been punished by Anaitis from Metro (with a disease) in her buttock; subsequently she sought out the goddess and asked her (what to do) and she dedicated this stone' (Table 1.22).

The upper leg and buttock are represented on this stone. The second text reads:

'Apphias, daughter of Theodotos; I thank Mother Leto, for she makes the impossible things possible; I had been punished (with a disease) in the buttock' (Table 1.23).

In another four cases we are dealing with women with diseased breasts (Table 1.18-21). It is interesting to note that in five cases the avenging deity is a fertility or birth goddess (Artemis Anaitis from Metro, Meter Leto, Meter Phileis); it was only natural to attribute afflictions of sensitive female organs to the anger of mother-goddesses. We find another gynaecological problem in the case of Apphia, who probably lost her virginity after she had stolen a stone (Table 1.29). ${ }^{34}$

Here again, we can find parallels between the diseases mentioned in the propitiatory inscriptions and in dedications. Breasts e.g. were one of the most common dedications in the Corinthian Asclepieion, 35 and in dedications women prayed for the health of their breasts (Table 2.34-38).

The 'pathology' of the sinners can be supplemented by reference to persons suffering in their legs and arms (Table 1.24-28). The son of another sinner died by accident, when a sickle fell on his foot. ${ }^{36}$ Finally we may register a man with diseased genitals (Table 1.30) and two cases of persons put into a state resembling death (íootóvaror). ${ }^{37}$

As we have seen, the vengeful gods of Lydia and Phrygia were not unimaginative in choosing penalties for sinners. However, in spite of the variety of diseases attested in the propitiatory inscriptions, it seems that diseases which could not easily be treated by secular medicine (ocular and mental disorders) were most commonly attributed to divine punishment. But for this we have to take into account not just the propitiatory inscriptions but also the dedications and vows related to divine cures from the same areas and addressed to the same gods. In Table 3, I have collected along the top bar all the diseases men-

34 Chaniotis (1990) 127-131; Petzl-Malay (1987) 468 suggested that Apphia had been punished with death.

35 Van Straten (1981) 124 nos. 15.77-114.

$36 T A M$ V.1 318. For suffering legs cf. table 2.13-31. Legs belong to the most common anatomical votives; see e.g. van Straten (1981) 108-113 nos. 25-31 (Asclepieion at Athens, 52 votives out of 401 ) and $105-143$ passim; Jackson (1988) 159-160; Nicolaou (1989) 201-318 nos. 2-8 (8 out of 18 hot-water bottles in the form of human organs found in Paphos are in the form of a foot or a leg). 
tioned in propitiatory inscriptions and dedications from Lydia and Phrygia and in the lefthand column the deities regarded as responsible either for the disease or for its cure (cf. Tables 1 and 2). As can be seen, practically any local deity was believed to be competent to cause any kind of health problem (and not only the diseases of human beings, but also those of animals). Some gods (Meter Phileis, Artemis Anaitis, and Mes Axiottenos) appear more often than others, but this is due to their wider popularity. And it is only natural that goddesses protecting fertility and birth (Artemis, Meter Phileis, Meter Leto) should appear in this Table in connection with breasts, genitals, and buttocks. But any indication that some deities were more closely connected with certain diseases is lacking, except for Thea Bryzi, to whom only two persons, both suffering with orthopedic problems, addressed their vows.

The local gods of Phrygia and Lydia were therefore regarded as competent not only to inflict all kinds of diseases upon sinners, but also to heal them. On this point these texts do not differ from the miraculous healings of Asclepius in Epidaurus or in Lebena, which demonstrate a vast variety of diseases. There is, however, a significant difference between the Lydian and Phrygian texts and the healing miracles narrated in inscriptions found in the Greek Asclepieia, namely in the terminology and the description of medical practices. The priests of Asclepius, who wrote the collections of miracles in Epidaurus and Lebena, included in their reports prescriptions and used current medical terms. ${ }^{38}$ Some of the cures of Asclepius described there resemble the current healing methods of physicians (see below, p. 335). On the other hand, in the Phrygian and Lydian inscriptions the expressions used simply refer to the afflicted organ (eyes, legs, breasts etc.; cf. Tables 1 and 2); the only exceptions are the words $\pi \varepsilon p i \pi v o l \alpha$ (otherwise unattested, perhaps a corrupt form of $\pi \varepsilon \rho(\pi v \varepsilon v \mu o v i \alpha)^{39}$ and $\pi \alpha \rho \omega t i \delta \varepsilon \zeta$, which occurs in medical works. ${ }^{40}$ These two words show at least an attempt to make an accurate diagnosis.

This observation leads to a consideration of the healing practices in these areas and in the local sanctuaries. There can be no doubt that even in the most remote areas of Asia Minor doctors did practise their profession; there are

$37 T A M$ V.1 179 b; Malay (1988) 150 no. 4.

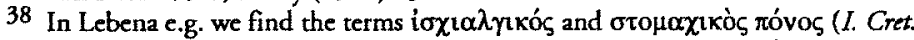

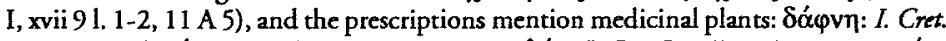

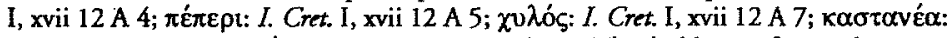

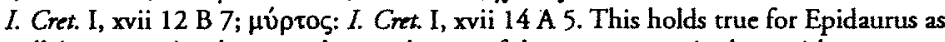
well (see note 1), where we observe the use of the current terminology with respect to

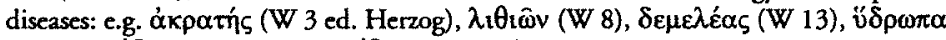

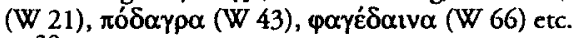

39 TAMV.1 247; cf. the commentaries of.Herrmann-Polatkan (1969) 51 with note 106; $B E(1970) 445$ no. 527.

40 TAM V.1 461 b; cf. for instance Dioscurides, De materia medica 2.80 .2 Wellmann; Ps.-Galen, In Hippocratis De humoribus commentarium 3.34 (16.484 K.). 
some references to i $\alpha \tau \rho o$ in propitiatory inscriptions as well. ${ }^{41}$ Thus we can assume that at least some general knowledge of medical practices and medical terminology could reach even the uneducated people who dedicated the inscriptions, or the priests who in some cases wrote them for them. And yet the villagers often preferred to turn to the local sanctuary for help rather than to the nearest doctor.

The 'cost, risk, uncertainty, discomfort or sheer pain of ancient medical treatment ${ }^{32}$ on the one hand and the belief in the omnipotence of the gods on the other explain why a person would turn to a healing deity for help. But in many cases gods and physicians worked together; for instance a certain Loukios in Cibyra addressed a dedication to Asclepius, after his genitals had been cured, but did not neglect to name the doctor who treated him; ${ }^{43}$ and even Asclepius' most fanatical supporter, Aelius Aristides, consulted physicians.

These undiscerning feelings towards secular and divine medicine find an interesting expression in a recently published propitiatory inscription:

'Because Prepousa, the freedwoman of the priestess, had made a vow for her son Philemon, that if he should become healthy without wasting money on doctors, she would write it on a stone, and although the vow had been fulfilled, she did not keep her promise, (therefore) the god demanded the vow now and punished the father Philemon; she fulfils her vow for her son and from now on she praises the god. 44

Prepousa's way of thinking is revealing of the mentality of these people. Her first priority was undoubtedly the saving of her sick son's life. She seriously considered going to the doctors, but in that case only one thing was certain, that she would waste her savings. Engaging an expensive doctor did not necessarily mean that her son would recover. Consequently a deal with Men Axiottenos was more appealing. It is true that the god too wanted a reward, but only after he had restored the health of her son. In the worst case Prepousa would lose her son, but not her money as well. Prepousa's narrative shows that a treatment by physicians was seriously taken into consideration, even if divine help was eventually sought. And we have to assume that at least in some cases the sick persons sought out the temple only after the doctors had failed to cure them.

41 The expenses for doctors (i $\alpha \tau \rho \mathrm{x} \alpha \dot{\alpha}$ ) are mentioned in TAM V.1 541, doctors (i $\alpha \tau \rho o$ ) in Varinlioglu (1989) 42 no. 2. For mentions of doctors in these areas see e.g. SEGVI 266; XXVI 1311; Buresch (1898) 55.

42 Jackson (1988) 138.

43 Robert (1937) 384-389; other examples ibid. 385-386. For priests with medical experience see below.

44 Varinlioğlu (1989) $42-43$ no. 2. 
In many cases the sick invoked divine help not because of the high charges of doctors, but simply because they held the anger of gods responsible for their illness. Since their illness did not have a natural cause, but originated in a known or unknown sin (committed by them or by one of their relatives), a cure could not possibly be attained by means of secular medicine, but only through expiation. ${ }^{45}$ One sinner recognizes that her fate lay in the hands of a god: 'She had been punished in a bad way and all humans had lost hope of her being saved; but she wrote down (the punishment) and erected the inscription and praises the mother'; 46 another sinner, Apphia, observes: 'for the goddess makes impossible things possible.' 77

Some texts give information on the way sinners asked the gods for help. ${ }^{48}$ We have for example the confession of Trophime who suffered from a mental disease; ${ }^{49}$ she consulted (ìpórnoev) the gods, in order to find out what she should do to end her punishment; unfortunately the text does not say if Trophime was actually cured. Another sinner, Theodoros, a bierodoulos who had sexual intercourse repeatedly and lost his sight, states that he had been rebuked by Zeus and Men and then cites the command of the god (probably given to him in an oracle): 50 'I have punished Theodoros for his sins in his eyes.' The consultation of gods is attested in many other propitiatory inscriptions, in which we find either the verb 'ask's1 or words which show the reaction of the deity. ${ }^{52}$ The divine answer was usually given by means of oracles. In several cases the god appeared to the sinner in a dream, but not necessarily during incubation in the temple. 53

We must now ask whether the cult personnel were actively involved in the healing process and in what way. Undoubtedly some priests had medical knowledge, as for instance the young priest Loukios in Kula, a student of the doctor Tatianos. ${ }^{54}$ But some dedications made in sanctuaries in the same re-

45 Cf. Meier (1949) 17 (in general); Danforth (1989) 76-83 (modern Greece).

46 Steinleitner (1913) 46 no. 19.

47 Buckler (1914-1916) 172-173 no. 2; on this text cf. Pleket (1977-1978) 89.

48 On this question in general see Pleket (1977-78) 90; Varinlioğlu (1983) 85-86; Petzl (1988) 155; Varinlioğlu (1989) 39.

49 TAMV.1 460.

50 Malay (1988) 151 no. 5; discussion of this text: Petzl (1988); Varinlioğlu (1989) 37-40.

51 'Eparôv: e.g. TAM V.1 460; Nolle (1987) 102-104; Herrmann-Varinlioğlu (1984) 6-7 no. 3 .

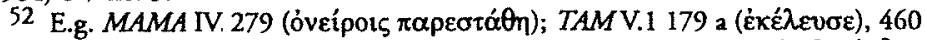

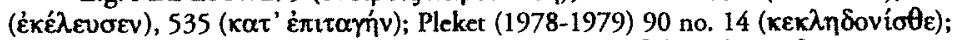

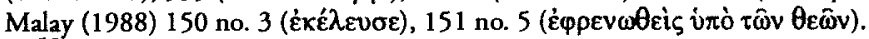

53 MAMA IV.279; cf. Sardis VII 94; SEG XXXIII 1013.

54 TAM V.1 432 (AD 214). Note that many propitiatory inscriptions have been found in Kula. 
gion imply that apart from the 'secular' medicine, which could also be practised by priests or devotees of the local gods, there was a quite distinct category of 'religious healing'. Hermogenes, cured by Zeus, informs us that 'Potta the daughter of Menekrates, the prophetess, had saved' him. ${ }^{55}$ As we can conclude from the office of Potta, the means of communication between the sick person and the deity was an oracle; the part played by the prophetess in the cure of Hermogenes must have been substantial, for Hermogenes regards her as his saviour. Another dedication directly reveals the involvement of a priestess: 'To Artemis Anaitis Charite the daughter of Apollonios (made the dedication) as a vow, because she had had a disease; but she has been cured by the priestess through incantation. ${ }^{56}$ Here we have magical spells, prayers, and ritual actions, not medical practices as may have ocurred in some Greek Asclepieia. ${ }^{57}$

This conclusion can be supported by some propitiatory inscriptions which speak of purifications and sacrifices which restore the health of a sinner. In one of them the aim of these rites is stated explicitly: 'I have propitiated the lord with purifications and sacrifices, so that he would save my body and he (...) restored (health?) to my body. 58 We get further information from three propitiatory inscriptions published and studied recently by E. Varinlioğlu, all referring to rites which had to be performed after the sinner had become sick.

(1) Posphoros: 'A six year old boy wore an unclean coat; the god punished him (pursued the affair), and he took it away with a triphônion (with a 'trinity of animals', a 'trinity of voices')'. 59

(2) Pollion: 'Because I crossed the boundary by mistake, as it was not proper, the gods punished him (...) As soon as the inscribed stone was erected, he took away (the sin) with a mole and a sparrow and a tuna; and the gods received the gifts by which the divine anger was dissolved, according to the custom, a modios of wheat, one prochus of wine; breakfast for the priests, one and a half kupros of wheat, one and a half prochus of wine, chick-peas and wheat groats. And I propitiated the gods for the sons of my sons and the grandchildren of my grandchildren.' 60

(3) Theodoros: 'He takes away the first sin with a sheep, a partridge, a mole. Second $\sin (. .$.$) He takes away with a 'piglet', a tuna, a fish. { }^{61}$ The third sin

55 TAMV.1 535.

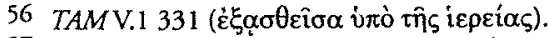

57 Meier $(1949,64)$ excludes an active involvement of priests with medical experience in Epidaurus, but this may hold true for Cos, Lebena, and Pergamon.

58 Steinleitner (1913) 59-60 no. 32. For purifications in ancient religious healing cf. Meier (1949) 59-60, 88-89.

59 Varinlioğlu (1989) 45-46 no. 4.

60 Varinlioglu (1989) $47-49$ no. 5; cf. Malay (1992) 76. 
(...) He takes away with a chicken, a sparrow, a pigeon, a kupros of barley and wheat, a prochus of wine, a kupros of clean (?) wheat for the priests, one prochus.' 62

Varinlioglu has rightly pointed out the analogy of the procedure described here with old oriental rituals. ${ }^{63}$ The sin together with the sickness is transferred to three different animals, ${ }^{64}$ which are then released to take the evil away. It is interesting to note that in the second text the trinity of animals represents the three basic elements of the world, the earth (mole), the air (sparrow), and the water (tuna). ${ }^{65}$ An analogous symbolic character of the animals used in these rituals can be recognized also in the third text. The first sin had been removed with the help of three animals representing three different elements, the earth (sheep), the sky (partridge), and the underworld (mole), whereas in the case of the second and third sins we have to do with trinities of animals of the same kind, i.e. three fish and three birds respectively. 66

At first sight these reports remind us of medical texts. We have a diagnosis (the sin and the sickness), a prescription (i.e. the prescribed rite) and a therapy (the 'taking away'). But the analogy is only an external one. The procedure has in reality nothing to do with healing, neither with practical medicine nor with popular healing methods, but only with magic. First of all, there is no sign of an individual treatment of each disease; the same prescription is followed by the blind Theodoros as well as by Pollion, i.e. the ritual transfer of their sins to animals.

On this point the propitiatory inscriptions differ from the healing miracles known from mainland Greece and western Asia Minor. We have, for example, the report of an unknown woman, found in the sanctuary of Asclepius in Lebena on Crete:

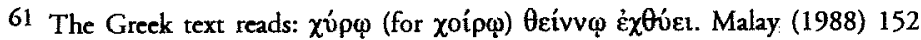
translates: 'with a piglet, a tunny-fish'; cf. Petzl (1988) 161: 'mit einem Ferkel und einem Thunfisch'. However, we expect here three animals, i.e. a triphonion (cf. the first and the third sin as well as the two parallel texts); we should read $\chi \dot{p} p \varphi$, Oeívv É $\chi$ '́ret, i.e. a 'piglet', a tunny, and (another) fish. Xoipos is the name of a fish (LS) s.v.); the whole context implies that we have to do with three different kinds of fish (cf. bellow).

62 Varinlioğlu (1989) 40; cf. also Petzl (1988) 158-163.

63 Varinlioglu (1989) 48-49.

64 The use of three different animals is a wide-spread religious custom; cf. the

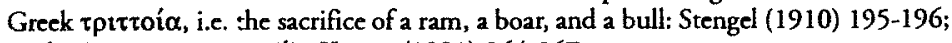
or the Roman suovetaurilia. Krause (1931) 264-267.

65 Cf. Petzl (1988) 162.

66 For the importance of symbols in religious healing cf. Danforth (1989) 54-58. 
'She had had on her little finger a severe wound, but has been cured by the god, who ordered her to burn a shell and put it on her finger, and to anoint her finger with a mixture of the oil of roses and mallow and olive oil. And so he cured her.' ${ }^{\prime 67}$

Or the inscription of P. Aelius Theon of Rhodos, found in the Asclepieion of Pergamon:

'For 120 days I have drunk nothing in the early morning, but have eaten fifteen corns of white pepper and half of an onion, as the god ordered, and so I have clearly been saved from many and great dangers.' 68

Such prescriptions often find their close parallels in the works of medical authors. ${ }^{69}$ Even in the more miraculous and less scientific reports from Epidaurus (see note 1), the priests who wrote them at least tried to give the impression that the god operated in a way analogous to that of secular doctors: e.g. 'the god cooked some kind of medicine' (W 9 ed. Herzog), 'the god opened his breast with a knife and removed the leech' (W 14), 'a young man of imposing figure put a medicine on his toe' (W 17), 'the god anointed him with an ointment on the head' (W 19), 'the god led him out of the sanctuary to a pond with extremely cold water and ordered him to bathe there' (W 37), 'the god rubbed an herb and then poured the juice in his eye' (W 40) etc. True, these are fairy tales, but at least they try to simulate real medical procedures. No trace of such an attempt is to be found in the propitiatory inscriptions.

But this is not their only difference from medicine. The primary aim of medicine is to cure sick people, whereas the primary aim of the rites which we find in the propitiatory inscriptions is to relieve a sinner from his sin. In the inscription of Theodoros the object of the verb 'he took away' is the word 'sin' and not the illness, i.e. his blindness. ${ }^{70} \mathrm{We}$ are not even sure if Theodoros was really healed. In the case of Polion, who probably recovered his health after he had erected his inscription, it is clear that he was not only concerned for his personal safety, but also for that of his descendants. 'I have propitiated the gods,' he writes on his stone, 'for the sons of my sons and the grandchildren of my grandchildren'; his descendants were not endangered because of his sick-

67 I. Cret. I, xvii 19.

68 Müller (1987) 194-199.

69 See e.g. Müller (1987) 212-233 on the new text from Pergamon. The healing powers of burnt shells mentioned in the text from Lebena are also refered to by Galen, De simplicium medicamentorum temperamentis ac facultatibus $11.26(12.345 \mathrm{~K}$.).

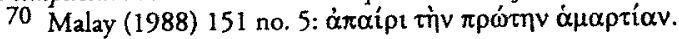


ness, but because of his $\sin$. It was a widespead belief in the ancient world that the individual's sin had consequences not only for him, but also for his family and his relatives, sometimes for the whole community. ${ }^{71}$ The propitiatory inscriptions offer much evidence for this attitude; one notes for instance the case of a whole family, whose members were afflicted in various parts of their bodies (eyes, breasts, legs) for an unknown $\sin .^{72}$ Some of the propitiatory inscriptions were even erected after the death of the sinner, by his descendants, anxious to end a series of punishments that could even afflict whole generations. ${ }^{73}$ But I must here abstain from further examples.

Even if propitiation was the primary concern of the sinners, their recovery was not a matter of minor importance. We cannot be sure that they were cured after the propitiation, but sometimes they were. We find expressions that imply cures ('I have been saved', 'I thank god' etc.). ${ }^{74}$ The confession of Antonia speaks explicitly of a cure: 'I entered the (holy) place with an unclean coat. After I had been punished, I confessed and dedicated the praise, because I became healthy. ${ }^{75}$ The anonymous donor of another text recovered his health through purifications and sacrifices. ${ }^{76}$ Stratonikos tells how the cut an oak belonging to Zeus Didymites unwittingly; the god pursued him, because he did not believe in his power, and put him into a condition resembling death; and after he had been saved from a great danger, he dedicated this and thanks the god.'77 Another text shows that the sick person at least did not lose his hope of a cure:

'Since the gods of the Perkenoi had given the forewarning to the disobedient people not to feed cattle in the grove of Zeus Orites, they punished Eumenes the son of Eumenes and put him into a state resembling death. But my Tyche gave me hope. ${ }^{78}$

71 See e.g. Moulinier (1952) 234-238; Parker (1983) 198-205.

72 TAMV.1 322. Cf. e.g. TAMV.1 318, 464, 509; Herrmann (1985) 255-259 no. 2; Malay (1988) 149-151 no. 4; Cremer-Nollé (1988) 203-205 no. 2; Varinlioğlu (1989) 42-43 no. 2; Chaniotis (1990), 128.

73 E.g. TAMV.1 179 a, 318, 326, 440, 464, 492, 510, 527.

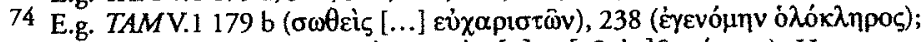

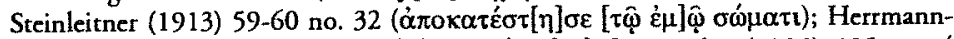

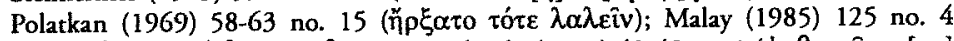

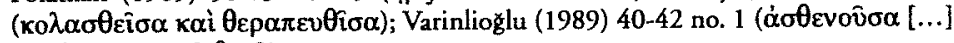

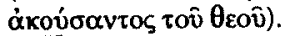

75 TAM V. 1238.

76 Steinleitner (1913) 59-60 no. 32.

77 TAMV.1 179 b.

78 Malay (1988) 150-151 no. 4. 
Since we find no traces of medical prescriptions, we have to assume that autosuggestion played an important role, especially in an illness of psychosomatic origin (mental illness, perhaps ocular disorders etc.). ${ }^{79}$

The group of testimonia on illness and cure presented here certainly confront us with more questions than we can answer. But I believe that they deserve a place in the history of ancient medicine as a direct source for the anxieties, ambivalent feelings, and hopes of people when confronted with illness.

79 Cf. the remarks of Danforth (1989) 50-63, 84-95 on religious healing, especially on modern Greek firewalking. 


\section{APpEndDX}

Table 1: Health problems in the propitiatory inscriptions of Lydia and Phrygia and the gods responsible for them.

I. Eyes

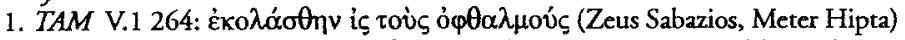

2. TAM V.1 322: representation of two eyes (Artemis Anaitis, Mes Tiamou)

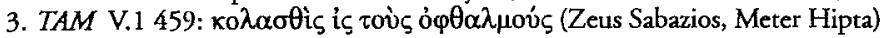

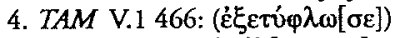

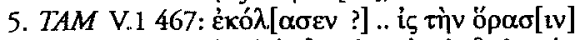

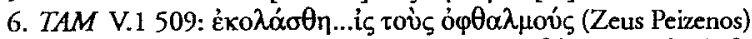

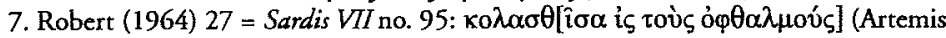
Anaitis)

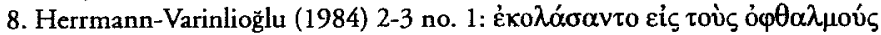
(Theoi Pereudenoi)

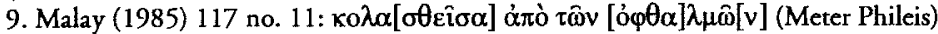
10. Malay (1985) 120 no. 31: representation of an eye (Meter Phileis)

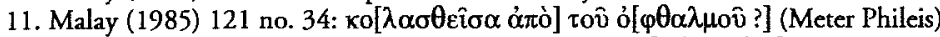

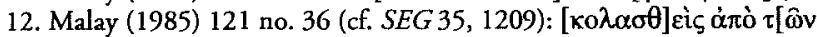
ó $\left.\varphi \theta \alpha \lambda_{\mu}\right] \omega \hat{\omega} v$ ? (Meter Phileis)

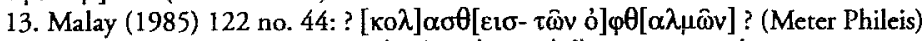

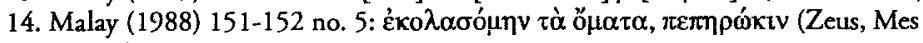
Axiottenos)

\section{Mental illness}

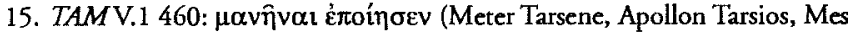
Axiottenos)

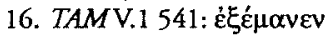

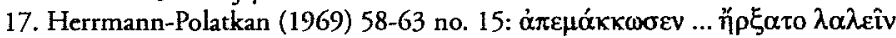
(Zeus Trosou)

\section{Breasts}

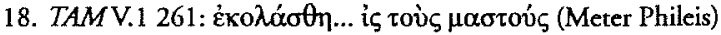

19. TAM V.1 322: representation of two breasts (Artemis Anaitis, Mes Tiamou)

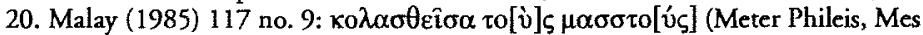
Tiamou)

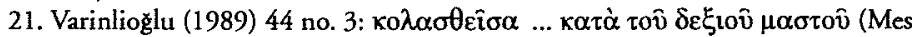
Axiottenos)

\section{Buttocks}

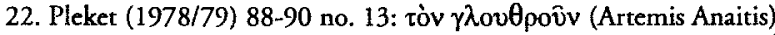

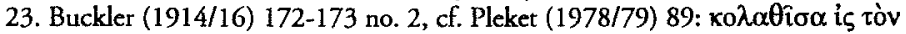
$\gamma \lambda$ ¡o $\theta$ póv (Meter Leto)

\section{Legs}

24. TAM V.1 322: representation of a leg (Artemis Anaitis, Mes Tiamou) 25. Varinlioglu (1983) 78-80 no. 2: representation of a leg (Zeus Orkamaneites) 26. Malay (1985) 116 no. 5: representation of a foot (Meter Phileis)

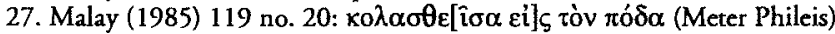




\section{ILLNESS AND CURES IN GREEK PROPITIATORY INSCRIPTIONS}

VI. Arms

28. TAM V.1 596: representation of an arm

VII. Loss of virginity

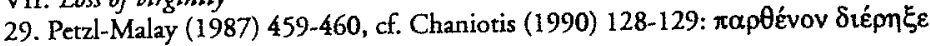
(Mes Axiottenos)

VII. Male genitals

30. Keil-Premerstein (1911) 25 no. 34 = Malay (1985) 125 no. 3: lateral view of the lower part of a male body, with genitals (Meter Phileis) 
Table 2: Health problems in vows and dedications of Lydia and Phrygia and the gods responsible for their cure

1. Eyes

1. TAM V.1 332: v̇สè

2. TAM V.1 347: representation of eyes (Mes Axiottenos)

3. TAM V.1 349: representation of eyes (Mes Ouranios, Mes Axiottenos)

4. TAM V.1 354: dedication of two persons; in relief a representation of two pairs of eyes (Meter Tarsene?)

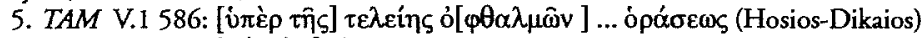

6. TAM V.1 598: ư $\pi \dot{\varepsilon} \rho$ ó $\varphi \theta \alpha \lambda \mu \omega \hat{v}$ (Hosios-Dikaios)

7. Van Straten (1981) 139 no. 49.1: representation of eyes (Zeus Alsenos)

8. Van Straten (1981) 140 no. 49.7: representation of eyes (Zeus Petarenos)

9. Malay (1985) 118 no. 19: ن̇ $̇ \grave{\rho}[\tau \hat{\omega} v$ ó $\varphi \theta \alpha \lambda \mu \omega \hat{\omega}]$ (Meter Phileis)

10. Malay (1985) 120 no. 28: representation of an eye (Meter Phileis)

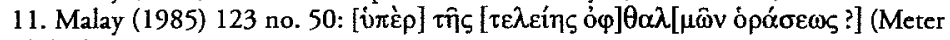
Phileis)

12. Sardis VII no. 97: representation of eyes (laso?)

II. Legs

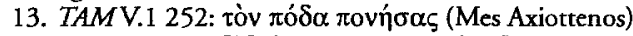

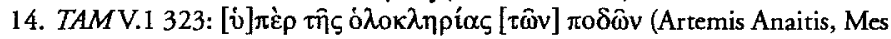

Tiamou)

15. TAMV.1 337: representation of a leg (Hosios-Dikaios)

16. TAMV.1 344: representation of a leg (Mes Axiottenos)

17. TAMV.1 402: representation of a leg ?

18. TAMV.1 504: representation of a foot

19. TAMV.1 533: v́kè

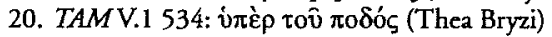

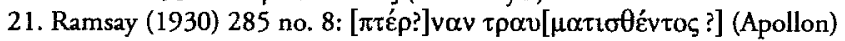

22. Van Straten (1981) 138 no. 47.2: representation of a leg (Thea Ourania)

23. Van Straten (1981) 139 no. 47.6: representation of a leg

24. Van Straten (1981) 139 no. 48.1 = MAMA IV 266: representation of a leg (Zeus

Trosou)

25. Van Straten (1981) 139 no. 49.4: representation of a leg (Zeus Alsenos)

26. Van Straten (1981) 139 no. 49.5: representation of a pair of legs (Zeus Alsenos)

27. Van Straten (1981) 139 no. 49.6: representation of a leg (Zeus Orochoreites ?)

28. Van Straten (1981) 140 no. 49.8: representation of a leg (Zeus Petareinos)

29. Varinlioğlu (1983) 77-78 no. 1: representation of a leg (Zeus Orkamaneites)

30. Malay (1985) 115 no. 2: representation of a leg (Meter Phileis)

31. Malay (1985) 118 no. 14: representation of a foot (Meter Phileis)

III. Arms

32. Van Straten (1981) 139 no. 49.2: representation of an arm (Zeus Petareinos)

33. Van Straten (1981) 139 no. 49.3: representation of an arm (Zeus Orochoreites)

\section{Breasts}

34. TAMV.1 324: ưtè $\rho \hat{\omega} v \mu \alpha \sigma \tau \hat{v} v$ (Artemis Anaitis, Mes Tiamou)

35. Keil-Premerstein (1911) 94 no. 6: representation of a pair of breasts

36. Van Straten (1981) 138 no. 47.4: representation of a pair of breasts (Theos

Hypsistos) 
37. Van Straten (1981) 138 no. 47.5: representation of a breast (Men Labanas, Zeus) 38. Malay (1985) 120 no. 32: representation of a large breast (Meter Phileis)

\section{Male genitals}

39. Malay (1985) 115 no. 1: representation of male genitals (Meter Phileis)

VI. Pregnancy-Sterility

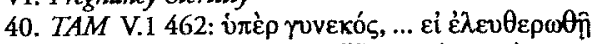

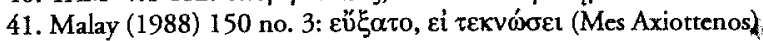

VII. Other parts of the body

42. Ears: TAM V.1 461 b: v่đè $\rho \alpha \rho \omega \tau i ́ \delta \omega v$

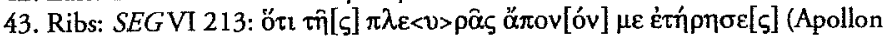
Propylaios)

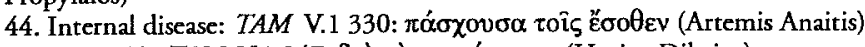

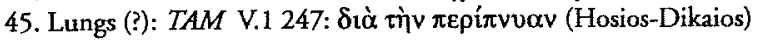


Table 3: Deities and diseases

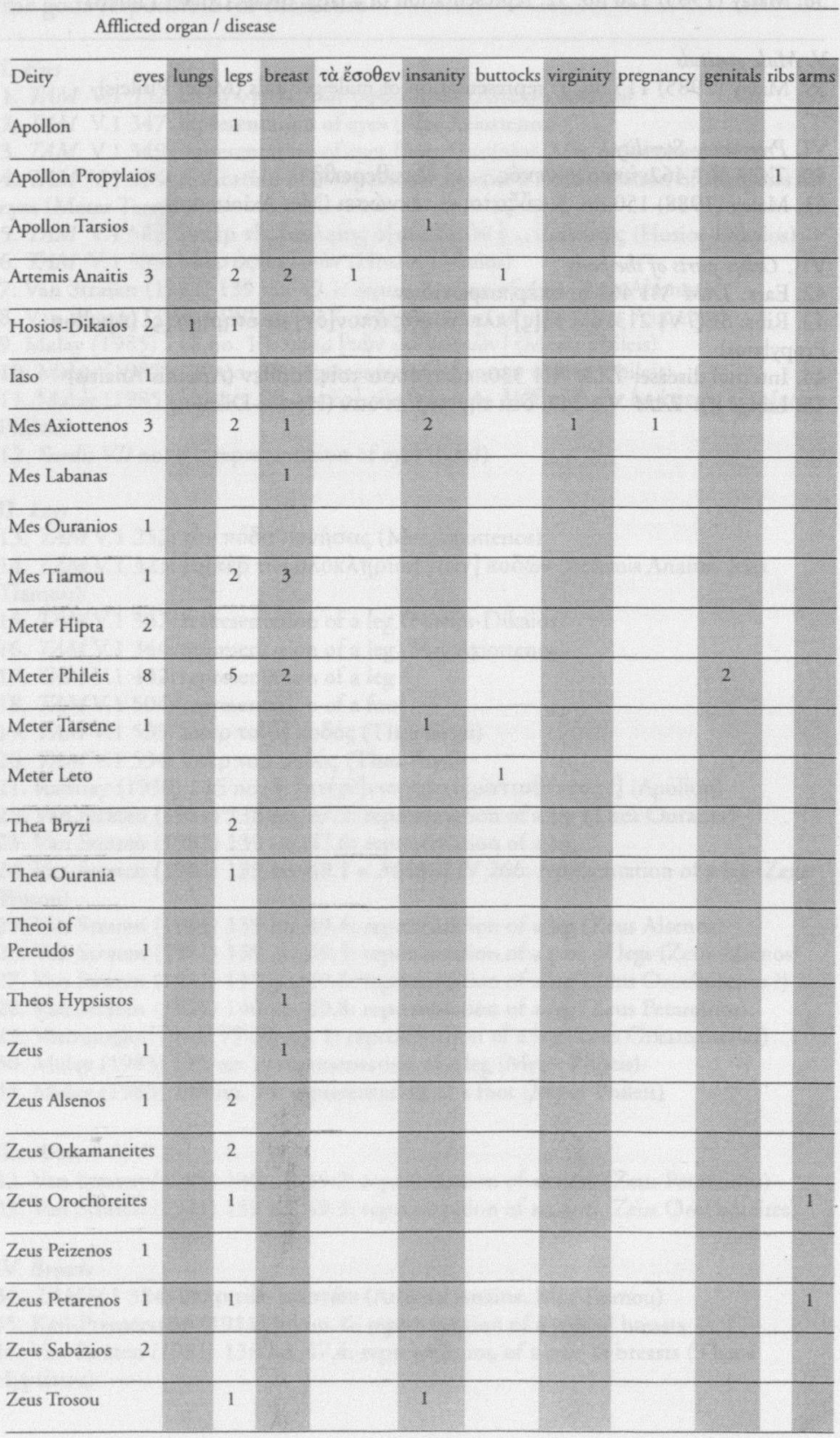




\section{BIBLIOGRAPHY}

Buckler, W.H. (1914-1916), 'Some Lydian Propitiatory Inscriptions', Annual of the British School at Athens 21, 169-183

Buresch, K. (1898), Aus Lydien. Epigraphisch-geographische Reisefrichte, Leipzig

Burkert, W. (1984), Die orientalisierende Epoche in der griechischen Religion und Literatur, Heidelberg

Chaniotis, A. (1988), Historie und Historiker in den griechischen Inschriften. Epigraphische Beiträge zur griechischen Historiographie, Stuttgart

- (1990), 'Drei kleinasiatische Inschriften zur griechischen Religion', Epigraphica Anatolica 15, 127-133

Cremer, M.L., Nollé, J. (1988), 'Lydische Steindenkmäler', Chiron 18, 199-214

Danforth, L.M. (1989), Firewalking and Religious Healing. The Anastenaria of Greece and the American Firewalking Movement, Princeton

Edelstein, E.J., Edelstein, L. (1945), Asclepius: A Collection and Interpretation of the Testimonies, Baltimore

Esser, A. (19612), Das Antlitz der Blindheit in der Antike, Leiden

Frisch, P. (1983), 'Über die lydisch-phrygischen Steininschriften und die “Confessiones" des Augustinus', Epigraphica Anatolica 2, 41-45

Herrmann, P., Polatkan, K.Z. (1969), Das Testament des Epikrates und andene neue Inschriften aus dem Museum von Manisa, Vienna

Herrmann, P., Varinlioğlu, E. (1984), 'Theoi Pereudinoi. Eine Gruppe von Weihungen und Sühneinschriften aus der Katakekaumene', Epigraphica Anatolica 3, $1-17$

Herrmann, P. (1985) 'Sühn- und Grabinschriften aus der Katakekaumene im archäologischen Museum von Izmir', Anzeiger der Osterreichischen Akademie der Wissenschaften in Wien 122, 248-261

Herzog, R. (1931), Die Wunderheilungen von Epidaurus, Leipzig

Jackson, R. (1988), Doctors and Diseases in the Roman Empire, London

Keil, J., Premersten, A. von (1911), Bericht über eine zweite Reise in Lydien, Vienna

Krause, C. (1931), 'Hostia', in: RE Suppl. 5, 236-282

Kudlien, F. (1978), 'Beichte und Heilung', Medizinhistorisches Journal 13, 1-14

Malay, H. (1985), 'The sanctuary of Meter Phileis near Philadelphia', Epigraphica Anatolica 6, 111-125

(1988), 'New confession-inscriptions in the Manisa and Bergama Museums', Epigraphica Anatolica 12, 147-152

(1992), ' $\Theta v \mu o \lambda v \tau \varepsilon i v$ and $\theta 0 \mu \nu \lambda v \sigma i ́ \alpha$ and the cult of Apollon Axyros in Lydia', Epigraphica Anatolica 20, 75-76

Malay, H., Petzl, G. (1985), 'Neue Inschriften aus den Museen Manisa, Izmir und Bergama', Epigraphica Anatolica 6, 55-68

Manganaro, G. (1985), 'La dedica di un aphidrysma di Mern Axittenos del 118 d.C.', Zeitschrift für Papyrologie und Epigraphik 61, 199=20j

Meier, C.A. (1949), Antike Inkubation und moderne Pychotherapie, Zürich

Müller, H. (1987), 'Ein Heilungsbericht aus dem Asklepieion von Pergamon', Chiron $17,193-233$

Nicolaou, I. (1989), 'Les bouillottes thérapeutiques de Paphos et leurs parallèles hors de Chypre', Bulletin de Correspondence Hellenique 113, 301-318

Nilsson, M.P. (1961), Geschichte der griechischen Religion. II ${ }^{2}$, Munich

Noorda, S. (1979), 'Illness and Sin, Forgiving and Healing', in: M.J. Vermaeseren (ed.), Studies in Hellenistic Religions, Leiden, 215-224

Parker, R. (1983), Miasma. Pollution and Purification in Early Greek Religion, Oxford 


\section{ANGELOS CHANIOTIS}

Petrazzoni, R. (1936), La confessione dei peccati. Volume III. Siria, Hittiti, Asia Minore, Grecia, Bologna

- (1954), 'Confession of sins and the classics', in: Essays on the History of Religion, Leiden, 55-67

Petzl, G. (1988), 'Sünde, Strafe, Wiedergutmachung', Epigraphica Anatolica 12, 155 166

Petzl, G., Malay, G. (1987), 'A New Confession Inscription from the Katakekaumene', Greek, Roman, and Byzantine Studies 28, 459-472

Pleket, H.W. (1978-1979), 'New Inscriptions from Lydia', Talanta 10-11, 74-91

Ramsay, W.M. (1930), 'Anatolica quaedam', Journal of Hellenic Studies 50, 263-287

Reitzenstein, R. (19273), Die bellenistischen Mysterienreligionen nach ibren Grundlagen und Wirkungen, Leipzig

Robert, L. (1937), Etudes anatoliennes, Paris (1964), Nouvelles inscriptions de Sardes, Paris

Rohde, E. (19253), Psyche. Seelencult und Unsterblichkeitsglaube der. Griecher, Tübingen

Siebenthal, W. von (1950), Krankheit als Folge der Sünde. Eine medizintistorische. Untersuchung, Hannover

Steinleitner, F.S. (1913), Die Beicht im Zusammenhange mit der sakralen Rechtspflege in der Antike, München

Stengel, P. (1910), Opferbräuche der Griechen, Leipzig-Berlin

Van Straten, FT. (1981), 'Gifts for the gods', in: H.S. Versnel (ed.), Faith, Hope, and Worship. Aspects of Religious Mentality in the Ancient World, Leiden, 65-151

Varinlioğlu, E. (1983), 'Zeus Orkamaneites and the expiatory inscriptions', Epignaphica Anatolica 1, 75-86

- (1989), 'Eine Gruppe von Sühneinschriften aus dem Museum ron Usak', Epigraphica Anatolica 13, 37-50

Zingerle, J. (1926), 'Heiliges Recht', Jabreshafte des Osterreichischen Archäologischen Institutes 23, Beiblatt, 5-72 